\title{
SUSTAINABle TOURISM DEVELOPMENT - ANALYSIS OF TOURISM DEVELOPMENT IN KOSOVO
}

\author{
Alberta Tahiri ${ }^{1}$; Idriz Kovaçi ${ }^{2}$ Fari Bushi $^{3}$ \\ University of Applied Sciences in Ferizaj, Faculty of Tourism and Environment, \\ Department of Tourism and Hotel Management, \\ Str. Rexhep Bislimi, 70000 Ferizaj, The Republic of Kosovo \\ e-mail: ${ }^{1}$ alberta.tahiri@ ushaf.net; ${ }^{2}$ idriz.kovaci@ ushaf.net; ${ }^{3}$ fari.bushi@ ushaf.net
}

\begin{abstract}
The purpose of this article is to provide a theoretical overview of sustainable tourism as a tourism system that focuses on qualitative development, taking into account the quality of life and prosperity of the population, without causing damage in other aspects.

The theoretical part deals with sustainable tourism and sustainable development. Based on these facts, it turns out that sustainable tourism is a subgroup of sustainable development. Thus, in this article there are given the differences between these two terms and other terms relevant to our research. It also provides an analysis of tourism development in Kosovo, including statistics on how much the tourism sector is financially supported by the Kosovo Government. Finally, a SWOT analysis of the current state of tourism in Kosovo is presented.
\end{abstract}

\section{Keywords}

Tourism; Sustainability; Sustainable tourism; Sustainable development.

\section{Introduction}

Economic and technical-technological activities in the contemporary national and international environment have created the conditions for the development of the concept of sustainable development globally.

The trend towards greater economic development leads to the increasing use of natural resources that are threatened with extinction, while new technologies being applied in the industrial, agricultural, construction and transport sectors can greatly endanger air, water and land quality, and cause an increase in the volume of toxic waste and hazardous materials. In this regard, the rapid development of tourism and the pressure exerted by tourist movements on the environment have an impact on a global level. That is why the concept of "sustainable tourism development" or "sustainable tourism" as a new trend in the travel industry is introduced today. Currently, tourists are interested in the so-called "green journey", where one person's stay in one place does not harm the environment of others [1, p. 60].

It is indisputable that tourism is one of the most powerful economic activities and an accelerator of economic development. With its impact on all spheres of economic and social life, tourism is ranked among the top five export industries in the world, in $83 \%$ of countries in the world [2]. It is a major source of foreign exchange revenues in $38 \%$ of world economies, a complex activity that affects GDP growth, investment and employment rates, a phenomenon that ensures intercultural communication between people, their socio-cultural connection and the development of their knowledge and experiences. 
Literature Review

\section{$1.1 \quad$ Tourism and Sustainability}

The sheer complexity of sustainability issues and sustainable tourism potentially requires a public and private sector response that lies outside the usual jurisdiction of tourism-specific governance. This may be an issue of spatial scale, in that a Government body may have either limited (or even no) jurisdictional authority over a policy problem, or it may be an issue of means with respect to the existence of operational policy processes, technologies and/or institutional arrangements. Perhaps the policy and managerial capacity to respond to issues of sustainable tourism may reflect the political acceptability of any solution (i.e. tax increases, greater regulation, concern over travel lifestyle change). Tourism is undoubtedly a major international industry that is critical to the economic and social well-being of many regions and people. However, it is also a major contributor to global change, hence the central problem of meeting the needs of the present without compromising the needs of future generations [3, p. 7-9].

\subsection{The Sustainable Development and the Sustainable Tourism}

The idea of adopting the sustainable development concept in the area of tourism appeared in the early ' 90 s, which generated sustainable tourism - an area that quickly gained importance both in academia and research, and in tourism practice/activity/industry. Sustainable tourism dissociates itself as a matter of principle from mass tourism and partially associates to alternative, contemporary tourism forms. In other words, sustainable tourism is primarily the opposite of mass tourism. This is defined as "a positive approach intending to reduce tensions and frictions created by the complexity of interactions between tourism industry, tourist, natural environment and the local communities as host of tourist" [4].

Sustainable development is the "development that meets the needs of the present without compromising the ability of future generations to meet their own needs".

Sustainable tourism is a sub-set of sustainable development. Sustainable tourism is a tourism system that encourages qualitative development, with a focus on quality of life and well-being measures, but does not aggregate quantitative growth to the detriment of natural capital [3, p. 1].

Tourism is a part of human life and an important factor in creating its social status. Tourism has become a means of protecting the environment and at the same time an important source of its destruction. The main international rules on tourism, which also include the main trends in its development, are:

- The relationship between tourism and sustainable development consisting of:

○ The economic importance of tourism,

$\circ$ The environmental importance of tourism,

- Potential effects of tourism,

- Potential benefits of tourism.

- The international community and the adoption of a new development model;

- Determining the carrying capacities for sustainable tourism [5, p. 280-286].

\subsection{Sustainable Tourism Development}

Sustainable Tourism Development is relatively new and has gained more significance in last 20 years. It is an adaptive concept emerging from the parent concept of sustainable development and therefore contributing towards the same objectives and principles related to 
the destination. Sustainable tourism focuses on quality, continuity and balance. Quality through sustainable tourism translates into a valuable experience for visitors in the context of improving quality of life of communities and brings forth the significance of the natural environment. "Sustainable tourism cannot exist without the continuity of the natural resources, culture and customs of host communities". This form of tourism aims to ensure a balance between all stakeholders including the tourism industry, social players, environmental representatives, the Government, the local authority and local communities. In order to ensure continuity of cultural, natural and local community resources, the management strategy has to involve long-term planning and stakeholder engagement. "If we protect the environment in such a way as to bring about in the long run economic misery, we would be defeating the whole purpose of development. If we promote economic wellbeing in the short run, and lead to environmental and social degradation, we will be winning one battle and losing another, with the end result of ending up worse in the long run" [6, p. 7].

\subsection{Sustainable Tourism as a Sub-set of Sustainable Development}

The study of the appropriate use of the physical environment by humankind serves to chart the history of environmental attitudes and how they are actioned.

Such research can offer profound insights into the manner in which exploitation of the environment occurs, the nature of environmental perceptions, conflicts and behaviours relative to the environment, and the development and analysis of environmental policies. Sustainability is an "essentially contested concept". That is, a concept the use and application of which is inherently a matter of dispute. The reason for this is the degree to which the concept of sustainable development is used to refer to a "balance" or "wise" use in the way in which natural resources are exploited. The appropriateness of such an approach and the very way in which "wise use" is defined will depend on the values and ideologies of various stakeholders.

However, the history of natural resource management suggests that sustainable development, including the sub-concept of sustainable tourism (see Figure 1), is one term among several which has emerged in an attempt to reconcile conflicting value positions with regard to the environment. Furthermore, it is argued that the terminology of "balance" is continuing to evolve, more recently with the notion of the "green economy" and "green economic growth". These concepts have already begun to infiltrate the lexicon of tourism [3, p. 16].

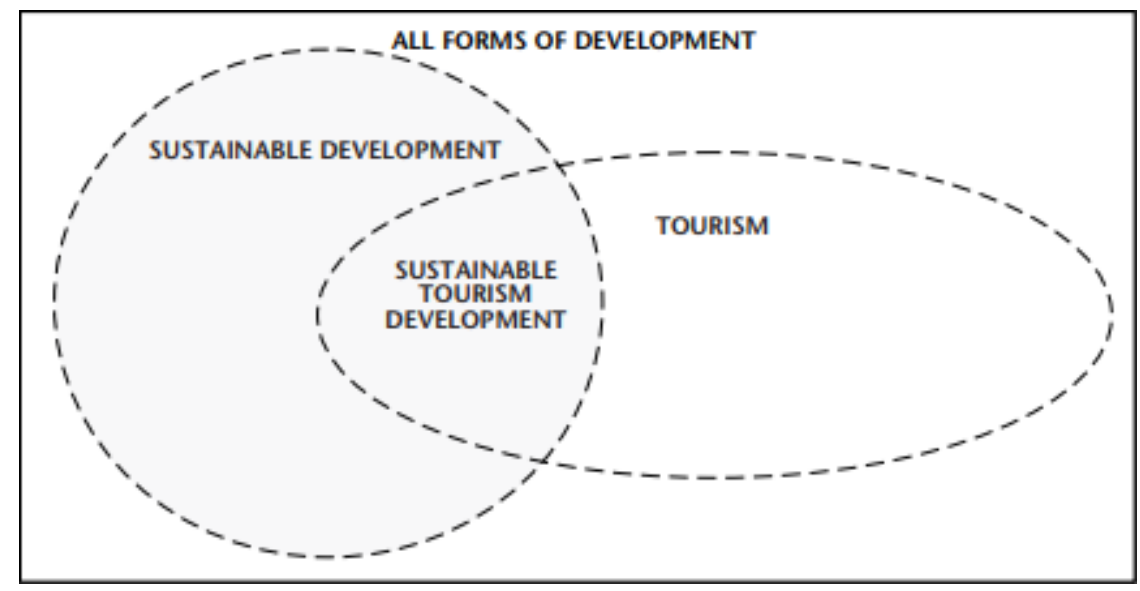

Source: [3]

Fig. 1: Sustainable tourism as a sub-set of sustainable development 


\subsection{Issues in Sustainable Tourism}

With its alluring premise of continued development that does not unduly harm a destination's natural and sociocultural environment, the idea of sustainable tourism has emerged as a priority objective of the global tourism sector since the mid-1990s. This is indicated in part by the extent to which it has been officially recognized and internalized by a broad array of international, regional and national organizations both internal and external to tourism. Yet, as attempts have subsequently been made to operationalize the concept in the actual planning and management of tourism businesses and destinations, various attendant issues and challenges have become increasingly apparent.

Issues in sustainable tourism can be summarized in:

- The inherent flexibility of sustainable tourism and the resulting possibility of weak and strong interpretations.

- The degree to which the semantics of sustainable tourism encourage the perpetuation of a possibly unsustainable status quo.

- The complexity of tourism systems, including their fuzzy boundaries, indirect and induced impacts, the influence of external (non-tourism) systems.

- The often unpredictable nature of relationships between cause and effect.

- Comprehensive and minimalist composite models of sustainable tourism.

- The final issue involves sustainable tourism indicators [7, p. 18-19].

\section{$2 \quad$ Methodology}

This paper is based on theoretical discussion about the topic in question. Thus, the methodology of this paper is based on literature review, which was summarized from various literary sources related to the issues of tourism, development and sustainability.To illustrate the topic, the research reports and the development of tourism in Kosovo analysis are presented in this article.

\section{$3 \quad$ Analysis of Tourism Development in Kosovo}

\subsection{Development of the Tourism Sector}

Tourism today is one of the largest industries in the world creating more jobs than most other sectors. Countries that are in the early stages of tourism development, such as Kosovo, have the potential to benefit from tourism, especially in reducing poverty and increasing the economic development. For tourism to thrive sustainably, public institutions must provide supportive legislation, an institutional framework conducive to private sector development, and ensure the quality assurance for tourists. This includes proper infrastructure, promotion of tourist potentials, good transport, visa facilitation and appropriate policies to stimulate demand growth.

According to the World Tourism Organization, Europe accounts for $41 \%$ of total international tourism admissions, as Southeast Europe is one of the fastest growing regions. In developing countries, tourism ranks sixth as a source of exchange in international trade. Given this, Kosovo may particularly benefit from participating in Balkan tourist tours.

Kosovo's tourism industry is still an emerging industry, at a very early stage of development compared to other Southeast European countries. This is largely due to a lack of investment for many decades, poor private sector tourism offers, a lack of educated staff, poor investor policies, and a lack of coordination between stakeholders and Government agencies. Although the number of tourists and overnight stays in Kosovo has increased significantly over the last 
ten years, the number of international visitors within a year is far from the region's average. The largest number of tourists visiting the country is during the summer. This is believed to be mainly due to the diaspora, which has a major impact on the local economy and the tourism sector, in particular [8, p. 6-7].

The legislation in the tourism industry, as in all other sectors, is a fundamental pillar that serves to regulate and monitor the organization and operation of all areas related to tourism activities. Over the years, due to the increasing complexity and competitiveness of this industry, various reforms and updates to tourism legislation have been developed in countries with potential tourism in order to create a healthy and sustainable tourism environment, thus generating economic prosperity for their communities. Without proper legislation and respect for the rule of law, the tourism sector cannot be organized, operated or have any positive economic impact on the community.

The tourism sector is broad and complex, and Kosovo's existing tourism law and regulations are not sufficient and designed to handle such complexity [9, p. 9].

According to the WTTC report, tourism, as of 2018, employs 319 million people. This figure is expected to increase to 421 million by 2029. In Kosovo, according to the report of the Labor Force Survey (2018), the number of employees in the field of tourism is around 28,500 people.

\subsection{The Level of Government Support for the Tourism Sector}

Tourism in Kosovo is managed and overseen by the Ministry of Trade and Industry, represented by a Division in the Department of Industry. The current administrative level of tourism in Kosovo is under-represented in this ministry, compared to the responsibilities and importance of the tourism sector for development and contribution to the country's economy.

With regard to the Government financial support for tourism, budget lines indicate that over the years the tourism sector has been poorly covered or not mentioned at all. The Government budget allocation for the Ministry of Trade and Industry (responsible for tourism) is very small, given that it has to cover many other areas and sectors within the ministry portfolio. The entire annual budget is spent through the main lines of the ministry, such as capital expenditures, goods and services, subsidies and transfers, wages and salaries, and public services. The tourism sector is not specifically mentioned in the lines where the budget was allocated $[9$, p. 11].

Tab. 1: Government budget allocation for the Ministry of Trade and Industry during the period 2012-2017

\begin{tabular}{|l|c|c|c|c|c|c|}
\hline \multicolumn{6}{|c|}{ Budget allocation of the Government of Kosovo for "MTI" (in Euro) } \\
\hline Year & $\mathbf{2 0 1 2}$ & $\mathbf{2 0 1 3}$ & $\mathbf{2 0 1 4}$ & $\mathbf{2 0 1 5}$ & $\mathbf{2 0 1 6}$ & $\mathbf{2 0 1 7}$ \\
\hline Amount & $4,188,780$ & $5,346,217$ & $4,876,369$ & $4,730,877$ & $4,557,200$ & $4,925,977$ \\
\hline
\end{tabular}

Source: [10]

Table 1 contains the data on the allocation of the Kosovo Government budget for the Ministry of Trade and Industry during the period 2012-2017.

According to available data, the Kosovo Government spends less than $0.3 \%$ of the annual budget for the entire Ministry of Trade and Industry, where tourism is represented by a Division and their budget dedicated to the tourism sector is the lowest in the region [9, p. 11]. Also, we can mention that the budget allocated for MTI for 2018 was 7,333,320€. 
Tab. 2: Budget allocated to cover the whole spectrum of tourism in Kosovo

\begin{tabular}{|l|c|c|c|c|c|c|c|}
\hline \multicolumn{6}{|c|}{ Budget allocated to cover the whole spectrum of tourism in Kosovo (in Euro) } \\
\hline Year & $\mathbf{2 0 1 0}$ & $\mathbf{2 0 1 1}$ & $\mathbf{2 0 1 2}$ & $\mathbf{2 0 1 3}$ & $\mathbf{2 0 1 4}$ & $\mathbf{2 0 1 5}$ & $\mathbf{2 0 1 6}$ \\
\hline Amount & 60,000 & 70,000 & 70,000 & 40,000 & 30,000 & 30,000 & 30,000 \\
\hline
\end{tabular}

Source: [9]

Table 2 contains the data on the budget allocated for the whole spectrum of tourism in Kosovo for the period of years 2010-2016. Due to lack of data year 2017 has not been presented.

Division of Tourism (under MTI) and Kosovo Investment and Enterprise Support Agency (KIESA - an agency that promotes and supports investment, exports, tourism, small and medium-sized enterprises (SMEs) and special economic zones, also under MTI) have low financial support (less than 100,000 euros per year) for the development and promotion of this sector [9, p. 11-12].

\section{Tab. 3: SWOT Analysis of the Current State of Tourism in Kosovo}

\begin{tabular}{|c|c|}
\hline & \\
\hline $\begin{array}{l}\text { and Europe; } \\
\text { Good and unique landscapes (rivers, } \\
\text { lakes, parks, mountains, waterfalls, etc.); } \\
\text { Cultural heritage assets; } \\
\text { Special cuisine services; } \\
\text { Multilingualism; } \\
\text { Hospitality; } \\
\text { Uncharted tourist destinations; } \\
\text { Friendly culture; } \\
\text { Reasonable prices; } \\
\text { Wealth in the historical sense and } \\
\text { historical countries sense; } \\
\text { It is already included in Western Balkan } \\
\text { tourist packages; } \\
\text { Traditional events, festivals, night life; } \\
\text { New airport and highways; } \\
\text { The potential for transit; } \\
\text { The current increase in Government } \\
\text { awareness of the tourism sector; } \\
\text { Attractive places and good weather } \\
\text { conditions; according to seasons; }\end{array}$ & $\begin{array}{l}\text { - There are no competing tourism laws and } \\
\text { regulations available; } \\
\text { - Lack of Government support for the } \\
\text { tourism sector; } \\
\text { - Lack of certified guides; } \\
\text { - Poor waste management; } \\
\text { - Lack of environmental protection } \\
\text { (especially of rivers, deforestation, and } \\
\text { waste disposal); } \\
\text { - There isn't a National Tourism Agency } \\
\text { (NTA)/a National Tourism Organization } \\
\text { (NTO) established; } \\
\text { - Lack of adequate tourism statistics; } \\
\text { - There isn't a strategy for tourism } \\
\text { development; } \\
\text { - Mismanagement of visitor centers in } \\
\text { different municipalities; } \\
\text { - Visa regime (especially towards countries } \\
\text { - with high potential for exporting tourists); } \\
\text { - High cost of flights; } \\
\text { - Vack of Government subsidies for flights; }\end{array}$ \\
\hline
\end{tabular}


- Kosovo's small area (fast connection between cities and tourist destinations);

- Large diaspora participation in the tourism market in Kosovo;

- Flexible and competitive business taxes;

Opportunities

- Attractive due to the post-war period and the peaceful environment (specific to some groups of tourists);

- Participation in major trade fairs and shows;

- Public relations media plan for transforming Kosovo's image;

- Creation of NT/NTO;

- Organizing family visits (FAM Trips) for key markets;

- Introducing new markets and products;

- Business meetings, incentives, business conferences and events;

- Heritage protection and promotion by UNESCO;

- Development of protected national parks and other tourist assets;

- Creation of joint tourist packages with the countries of the region;

- Maximizing the use of EU funds for cross-border cooperation for the development of cross-border tourism;

- Development of tourist brands;

- Attracting foreign investment related to tourism;

- Increasing cooperation with international donors, maximizing the use of funds and transfer knowledge to the sector;

- Increasing domestic tourism. the region;

- Lack of municipal support for the tourism sector;

- Lack of advertising Kosovo as a tourist destination.

\section{Threats}

- There isn't national tourism strategy;

- Very small budget for the tourism sector;

- Increasing competition in the region (Western Balkans);

- Lack of training/education in the hotel industry;

- Lack of development of products and services;

- Price competition in the region;

- High cost of flights compared to some of the countries in the region (e.g. Macedonia);

- Lack of licensing and classification for tourism services and institutions;

- Lack of interest and awareness to study courses related to tourism and catering;

- Lack of municipal projects available in the tourism sector;

- Low interest in using funds allocated by international organizations for tourism projects;

- Poor coordination among line ministries;

- Fragile political situation that affects the image of Kosovo's media tree;

- Lack of Public-Private Partnership (PPP) initiatives;

- Kosovo is seen as a transit destination in the region (low number of nights spent);

- Undeveloped infrastructure.

Source: [9]

\section{Conclusion}

Based on all of the facts stated above we could say that: 
- Kosovo as a young country, having little experience in the tourism industry and knowing that there are many challenges in the further development of tourism, must take the step of development and follow the global tourism industry to develop this sector in compliance with international standards.

- The budget allocated by the Kosovo Government for the tourism sector needs to be increased so that this sector can grow faster.

- Knowing that the current situation of tourism development in Kosovo isn't so satisfactory, improvements should be made to tourism legislation in order to comply with tourism laws first, and then to make improvements and reorganizations in policies, procedures and standards on tourism which support the development of the tourism sector.

- Tourist destinations must be protected from pollution because cleanliness of the environment is one of the key elements for these destinations to attract domestic and foreign tourists and visitors.

- We noticed that Kosovo does not have a National Tourism Agency (NTA) / National Tourism Organization (NTO) established. If NTA / OKT were established, they could facilitate the functioning of the tourism sector by providing professional advice and support for the creation of sustainable tourism plans and policies, engaging in marketing and promoting the country and providing a general visionary orientation for the development of the tourism sector.

- Also, in terms of sustainable tourism development and regional competitiveness, Kosovo is currently unable to follow development trends and be competitive.

\section{Literature}

[1] TAHIRI, A.; KOVAÇI, I.: Management in Tourism, Theoretical Managerial Approach. Research Center, Peja, 2017. ISBN 978-9951-8912-4-0.

[2] FAYED, H; FLETCHER, J.: Report: Globalization of Economic Activity: Issues for Tourism. Tourism Economics. 2002, Vol. 8, Issue 2, pp. 207-230. DOI: $10.5367 / 000000002101298070$

[3] HALL, M.; GÖSSLING, S.; SCOTT, D.: The Routledge Handbook of Tourism and Sustainability. Routledge Taylor \& Francis Group, London and New York, 2015. ISBN 978-0-203-07233-2.

[4] DUMBRAVEANU, D.: Principles and practice of sustainable tourism planning. [online]. Human Geographies. 2007, Vol. 1, Issue 1. Available from WWW: https://www.researchgate.net/publication/265745294

[5] KOJA, V.; GORICA, K.: The Fundamentals of Tourism. albPAPER, Tirana, 2010. ISBN 978-99956-34-59-9.

[6] CASSAR, G. (ed.): Sustainable Tourism Management, A Collection of Studies from Malta, Lebanon and Jordan. [online]. Heland Project, University of Malta, 2015. ISBN 978-99957-886-2-9. Available from http://www.enpicbcmed.eu/sites/default/files/heland_sustainable_tourism_management studies.pdf

[7] WEAVER, D. B.: Sustainable Tourism: Theory and Practice. Elsevier ButterworthHeinemann, 2006. ISBN 075066438 X. 
[8] ZEJNA, I.: Tourism Development through Efficient Policies and Legislation: Identifying potential reform steps in tourism policy and legislation. [online]. Democracy for Development Institute, Prishtina, July, 2017. ISBN 978-9951-608-56-5. Available from $\quad$ WWW:

content/uploads/2017/07/D4D_PI_10_SHQ_WEB.pdf

https://d4d-ks.org//wp-

[9] USAID EMPOWER Private Sector: Analysis of the current situation in the tourism sector in Kosovo. [online]. This report was produced for review by the United States Agency for International Development (USAID) and Swedish International Development Cooperation Agency (SIDA), Prishtina, April, 2018. Available from WWW: $\quad$ https://mti.rks-gov.net/desk/inc/media/BEE9A796-9FA3-4254-8528AB86C722CFF2.pdf

[10] GAP INSTITUTE: Ministry of Trade and Industry. How does the State spend our money? [online]. 2016. [accessed 2020-01-30]. Available from WWW: https://www.institutigap.org/spendingsEng/?ministry-of-trade-andindustry/0/2016\#/ /ministry-of-trade-and-industry 
Článek poskytuje teoretický přehled o udržitelném cestovním ruchu jako o systému cestovního ruchu, který se zaměřuje na kvalitativní rozvoj s ohledem na kvalitu života a prosperitu obyvatelstva, aniž by způsobil škodu v jiných aspektech.

Udržitelný cestovní ruch je podskupinou udržitelného rozvoje. V článku jsou uvedeny rozdíly mezi těmito dvěma termíny a dalšími pojmy relevantními pro náš výzkum. Je analyzován rozvoj cestovního ruchu $\mathrm{v}$ Kosovu, včetně statistik o finanční podpoře cestovního ruchu kosovskou vládou. Na závěr je představena SWOT analýza současného stavu cestovního ruchu v Kosovu.

\section{DiE NACHHALTige ENTWICKLUNG DER TOURISMUSBRANCHE - EINE ANALYSE DER ENTWICKLUNG DER TOURISMUSBRANCHE IM KOSOVO}

Der Artikel gewährt einen theoretischen Überblick über den nachhaltigen Tourismus als System, welches sich auf die kreative Entfaltung unter Berücksichtigung der Lebensqualität und der Prosperität der Einwohnerschaft konzentriert, ohne dabei in anderen Aspekten Schaden zu verursachen.

Der nachhaltige Tourismus ist eine Untergruppe der nachhaltigen Entwicklung. Im Artikel werden die Unterschiede zwischen diesen beiden Termini und weiteren für unsere Untersuchung relevanten Begriffen angeführt. Wir analysieren die Entwicklung des Reiseverkehrs im Kosovo, inklusive der Statistiken über die finanzielle Unterstützung der Tourismusbranche seitens der kosovarischen Regierung. Am Schluss wird eine SWOTAnalyse des gegenwärtigen Zustands der Tourismusbranche im Kosovo vorgestellt.

\section{ZRÓWNOWAŻONY ROZWÓJ TURYSTYKI - ANALIZA ROZWOJU TURYSTYKI W KosowIE}

Artykuł przedstawia teoretyczne informacje dotyczące zrównoważonej turystyki ujmowanej jako system turystyki, który skupia się na jakościowym rozwoju przy uwzględnieniu jakości życia i dobrobytu ludności bez powodowania szkód w innych dziedzinach.

Zrównoważona turystyka jest podgrupą zrównoważonego rozwoju. W opracowaniu przedstawiono różnice pomiędzy tymi dwoma pojęciami oraz innymi pojęciami związanymi z naszymi badaniami. Analizie poddano rozwój turystyki w Kosowie oraz dane statystyczne dotyczące dofinansowania turystyki przez rząd w Kosowie. Na zakończenie przedstawiono analizę SWOT obecnego stanu turystyki w Kosowie. 